\title{
Insulin sensitivity in Turner's syndrome: influence of GH treatment
}

\author{
Giorgio Radetti, Bruno Pasquino, Elena Gottardi, Isabella Boscolo Contadin ${ }^{1}$, Gianluca Aimaretti ${ }^{2}$ and \\ Franco Rigon ${ }^{1}$ \\ Department of Paediatrics, Regional Hospital, via L. Boehler 5, 39100 Bolzano, Italy, ${ }^{1}$ Department of Paediatrics, University of Padua, Padua, Italy and \\ ${ }^{2}$ Endocrinology and Metabolism Unit, University of Turin, Turin, Italy \\ (Correspondence should be addressed to G Radetti; Email: giorgio.radetti@asbz.it)
}

\begin{abstract}
Objective: Excessive GH secretion may lead to secondary diabetes mellitus, while prolonged GH treatment may accelerate the onset of type 2 diabetes mellitus in predisposed individuals. Turner's syndrome (TS) patients are a population at risk since they have reduced glucose tolerance (GT) spontaneously and because they are usually treated with high doses of GH.

Design and methods: The aim of the study was to evaluate insulin sensitivity (IS) and glucose tolerance (GT) in a group of TS patients treated with GH for a period of 6 years. Forty-seven TS girls were included in the study. GH was administered at a mean weekly dosage of $0.35 \mathrm{mg} / \mathrm{kg}$, injected subcutaneously over 6-7 days. GT was assessed according to the criteria of the Expert Committee on the Diagnosis and Classification of Diabetes Mellitus. IS was evaluated with the quantitative insulin sensitivity check index (QUICK-I).

Results: No significant increase of impaired GT was observed in the patients during the follow-up period, while a reduced IS was detected. IS in TS patients was already lower than in prepubertal controls $(P<0.001)$ before starting treatment and further decreased during the first year of therapy $(P<0.05)$, and then remained stable over the following years. No correlation was found between QUICK-I, body mass index, years of treatment, onset and duration of puberty. One patient became diabetic during the course of treatment.

Conclusions: GH treatment in TS girls does not significantly increase the prevalence of impaired GT or type 2 diabetes mellitus, while it does, however, decrease IS.
\end{abstract}

European Journal of Endocrinology 151 351-354

\section{Introduction}

Height prognosis in girls with Turner's syndrome (TS) has significantly improved following the introduction of growth hormone $(\mathrm{GH})$ treatment, in particular when started early and if higher doses of GH are given $(1-4)$. This kind of treatment approach raises, however, some concern about the potential diabetogenic effect of excessive GH concentrations (5-7). An impaired glucose tolerance has been seen in TS subjects before starting GH treatment (8) and also in TS adults who had never been treated with GH $(9,10)$. Previous studies have shown that GH treatment does not worsen glucose tolerance in TS girls, while inducing insulin resistance $(11-14)$. Even if insulin returns to close to pretreatment levels after $\mathrm{GH}$ withdrawal (12), it is not yet known whether such a long period of insulin resistance could influence carbohydrate tolerance in adulthood. In this paper, we report our experience with regard to the influence of $\mathrm{GH}$ treatment on glucose tolerance and insulin sensitivity in TS girls, evaluated by the quantitative insulin sensitivity check index (QUICK-I) (15).

\section{Subjects and methods}

\section{Subjects}

We evaluated 47 TS girls who were treated with GH and regularly followed-up at the Department of Paediatrics of the Regional Hospital of Bolzano (12 patients) and at the Department of Paediatrics, University of Padua (35 patients). At the beginning of treatment the chronological ages were $8.2 \pm 2.8$ years, height standard deviation score (SDS) - 2.25 \pm 0.77 and body mass index (BMI) SDS $0.8 \pm 2.0$. At the end of the study, 6 years later, the chronological ages were $12.6 \pm 3.1$ years, height SDS $-1.58 \pm 3.13$ and BMI SDS $0.79 \pm 1.59$. Forty-seven TS patients were examined during the first 2 years of treatment and 35, 27, 23 and 20 of them during the 3rd, 4th, 5th and 6th year respectively. Their clinical characteristics at the beginning of $\mathrm{GH}$ treatment and at the end of the study are summarized in Table 1. Chromosomal analysis showed a $45, \mathrm{X}$ karyotype in $40 \%$ of the subjects, structural abnormalities in $44 \%$ and a mosaicism in $16 \%$. Three patients had one diabetic parent and 
another one had a father and grandfather who were both diabetic. Five (10.7\%) of them suffered from Hashimoto's thyroiditis; only three of them, however, were on L-thyroxine. Eighteen (39.3\%) were affected with cardiac anomalies such as aortic coarctation, bicuspid valves and ventricular septal hypertrophy. Puberty started spontaneously in 14 (29.7\%) girls and was pharmacologically induced with low doses of ethinylestradiol (Amsa, Italy) (5 $\mathrm{g}$ daily) in 13 $(27.6 \%)$ girls at a mean age of $12.4 \pm 1.68$ years. At the end of the study 11 girls were pubertal (either spontaneously or pharmacologically); the mean period from the appearance of breast development was $2.0 \pm 1.4$ years. The treatment regimen with $\mathrm{GH}$ was the same in both centres, i.e. $0.35 \mathrm{mg} / \mathrm{kg}$ per week, given subcutaneously over 6-7 days. All patients had a regular auxological follow-up every 6 months. Forty girls, 20 prepubertal and 20 pubertal, mean age $10.4 \pm 4.4$ years, of normal height and body weight, were selected as controls and matched with the patients, according to chronological age and pubertal status. The ethical committee of the hospital approved the study and informed consent was obtained from the parents.

\section{Study design}

At the beginning of GH treatment and yearly thereafter, the patients were admitted to hospital after an overnight fast for the evaluation of glucose tolerance and bone age. BMI $\left(\mathrm{kg} / \mathrm{m}^{2}\right)$ was calculated and expressed as SDS (16). Height measures were also converted to SDS for chronological as well as for bone age (17). Bone age was assessed according to Greulich \& Pyle (18). All patients underwent a standard oral glucose tolerance test (OGTT): $1.75 \mathrm{~g}$ glucose $/ \mathrm{kg}$ body weight up to $75 \mathrm{~g}$ with blood samples taken at $0,30,60,90$ and $120 \mathrm{~min}$, in order to evaluate glucose and insulin levels.

Glucose tolerance and diabetic status were defined according to the Expert Committee on the Diagnosis and Classification of Diabetes Mellitus (19): impaired glucose tolerance: 2 -h level above $7.8 \mathrm{mmol} / \mathrm{l}(140 \mathrm{mg} / \mathrm{dl})$ and below $11.1 \mathrm{mmol} / \mathrm{l}(200 \mathrm{mg} / \mathrm{dl})$; diabetic status: 2-h level above $11.1 \mathrm{mmol} / \mathrm{l}(200 \mathrm{mg} / \mathrm{dl})$.

Insulin sensitivity was evaluated with QUICK-I = $1 /\left[\log \left(\mathrm{I}_{0}\right)+\log \left(\mathrm{G}_{0}\right)\right]$, where $\mathrm{I}_{0}$ is the fasting insulin and $G_{0}$ the fasting glucose (15).

Table 1 Clinical findings of the TS girls at the beginning of GH treatment and at the end of the study.

\begin{tabular}{lcccc}
\hline & $\begin{array}{c}\text { Chronological } \\
\text { age (years) }\end{array}$ & $\begin{array}{c}\text { Bone age } \\
\text { (years) }\end{array}$ & $\begin{array}{c}\text { Height } \\
\text { (SDS) }\end{array}$ & $\begin{array}{c}\text { BMI } \\
\text { (SDS) }\end{array}$ \\
\hline Beginning & $8.2 \pm 2.8$ & $6.9 \pm 2.7$ & $-2.25 \pm 0.77$ & $0.8 \pm 2.05$ \\
End & $12.6 \pm 3.13$ & $11.2 \pm 2.46$ & $-1.58 \pm 1.05^{*}$ & $0.79 \pm 1.59$ \\
\hline
\end{tabular}

$* P<0.0001$.

\section{Assay}

Serum glucose was measured with automatic analyzers, using a hexokinase catalysed glucose oxidase method. Serum insulin was measured with an immunoradiometric assay (Immulite 2000 Insulin; DPC, Los Angeles, CA, USA) which has intra- and interassay coefficients of variation of $8.3 \%$ and $8.6 \%$ respectively.

\section{Statistical analysis}

Data are expressed either in absolute values (means \pm S.D.) or as a percentage. Paired Student's $t$-test was used for the statistical analysis of the data. A $\chi^{2}$ test was used to verify differences between frequency of impaired glucose tolerance. One-way analysis of variance was used to compare differences in insulin sensitivity between patients and control subjects. The correlation between variables was sought by calculating the Pearson coefficient. A $P$ value of less than 0.05 indicates statistical significance.

\section{Results}

\section{Auxology}

Following treatment with GH a significant increment in height SDS $(P<0.0001)$ was observed, while BMI SDS remained stable (Table 1 ).

\section{Glucose tolerance}

During the study period no significant increase in the number of cases with impaired glucose tolerance was observed. Impaired glucose tolerance was present in $4.2 \%$ of the subjects before starting treatment and in $10 \%$ of the 20 girls at the end of the survey (Fig. 1). Seven patients with an impaired glucose tolerance at some point during treatment subsequently normalised their glucose tolerance, without suspending treatment but following only dietary advice. Only one case of diabetes was recorded in a patient who did not have any risk factors such as obesity, familial or impaired glucose tolerance before starting GH therapy. At the onset of diabetes, fasting plasma glucose was $7.1 \mathrm{mmol} / \mathrm{l}$ $(128 \mathrm{mg} / \mathrm{dl})$ and the $2-\mathrm{h}$ glucose level on OGTT was $13.2 \mathrm{mmol} / \mathrm{l}(238 \mathrm{mg} / \mathrm{dl})$. Fasting insulin level was $28 \mathrm{mU} / \mathrm{l}$ and the 2 -h insulin level on OGTT was $175 \mathrm{mU} / \mathrm{l}$. The patient had also glycosuria $(210 \mathrm{mg} / \mathrm{dl}$; $11.6 \mathrm{mmol} / \mathrm{l}$ ) and showed an hemoglobin ( $\mathrm{Hb}) \mathrm{Alc}$ of $6.8 \%$ (normal value $<5.4 \%$ ). Markers of humoral islet cell autoimmunity, such as antibodies against islet cells, glutamic acid decarboxylase, insulin and tyrosine phosphatase, were absent. GH treatment was therefore stopped and 6 months later the patient had only an impaired glucose tolerance (2-h glucose level on OGTT was $10.9 \mathrm{mmol} / \mathrm{l}(196 \mathrm{mg} / \mathrm{dl}))$ while HbA1c decreased to $5.6 \%$ and the patient no longer had any glycosuria. 


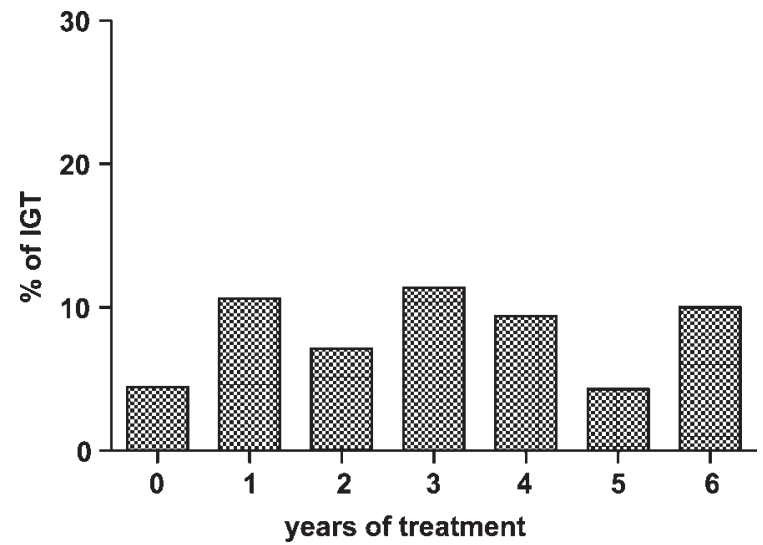

Figure 1 Prevalence of impaired glucose tolerance (IGT) in TS girls on $\mathrm{GH}$ therapy.

\section{Insulin sensitivity}

Before recombinant human GH treatment, insulin sensitivity in TS girls was clearly lower than in prepubertal controls as expected $(0.370 \pm 0.05$ vs $0.405 \pm 0.04$; $P<0.001)$. Insulin sensitivity significantly decreased during the first year of therapy $(0.370 \pm 0.05$ vs $0.344 \pm 0.02 ; P<0.05)$, with no further reduction over the following 6 years (Fig. 2). After 6 years of treatment, however, insulin sensitivity was still significantly lower in TS subjects than in pubertal controls $(0.325 \pm 0.02$ vs $0.355 \pm 0.04 ; P<0.05)$.

\section{Correlations}

No correlation was found at any time between QUICK-I, BMI, years of treatment, onset and duration of puberty.

\section{Discussion}

The results of this survey have shown that GH treatment leads to a significant catch-up growth in TS girls

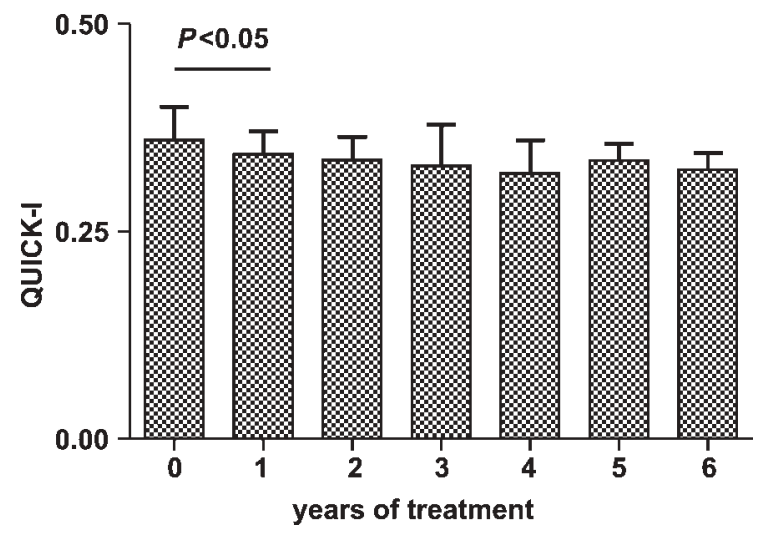

Figure 2 Mean \pm S.D. insulin sensitivity (QUICK-I) in TS girls on GH therapy. without further worsening glucose intolerance in the great majority of them. Insulin sensitivity which, in agreement with another report (20), was already lower than in controls before starting GH treatment, decreased significantly over the first year of treatment. No further reduction was observed over the following years however, probably because of the beneficial effect of $\mathrm{GH}$ on body composition leading to a reduction of body fat. Insulin sensitivity always remained lower than in the control group. Furthermore, one patient, without any family history of diabetes, showed a diabetic response to OGTT, which turned to impaired glucose tolerance 6 months after $\mathrm{GH}$ treatment was suspended.

Our findings agree with two other studies concerning short normal children (21) and children with PraderWilli syndrome (22), similarly showing a reduced insulin sensitivity shortly after the beginning of GH treatment. There is some debate as to whether a reduced insulin sensitivity is only a transient phenomenom $(22-24)$ or a persistent one $(25,26)$ as shown in this study. Differences in patient selection, body composition and different doses of GH treatment among various studies probably account for such discrepancies.

In our patients, the reduced insulin sensitivity could have been caused by changes in body weight, by a puberty-related increase of sex hormones and/or by treatment with GH. However, since no correlation between QUICK-I, BMI and puberty was found, GH should be considered the main factor responsible for the decrease in insulin sensitivity. GH therapy in fact, by increasing lipid oxidation and thus circulating free fatty acids levels $(23,24)$, may reduce the uptake of glucose in skeletal muscle $(26,27)$.

As a consequence, higher serum insulin levels were observed during long-term GH treatment (12) which, however, return towards pretreatment values after the discontinuation of GH therapy. Serum insulin levels, on the other hand, only partly reflect tissue insulin sensitivity and different degrees of sensitivity can thus be observed for a given amount of insulin (28). In order to better evaluate tissue responsiveness to insulin we therefore used the QUICK-I which is a simple, accurate and reproducible method, correlating very well with the hyperinsulinaemic euglycaemic glucose clamp and the minimal model analysis (15), and is thus suitable for population studies.

The main finding of this study is that, apart from the only one patient who became diabetic, glucose tolerance did not worsen in TS patients during GH treatment, while a significantly reduced insulin sensitivity was detected. Insulin resistance is an established risk factor for the development of type 2 diabetes mellitus (29), atherosclerosis, dyslipidaemia and hypertension $(30,31)$ and, thus, even if an improvement is reported when GH is no longer administered, we consider that a longer follow-up is needed to verify whether such a long period of insulin resistance could influence carbohydrate tolerance in adulthood. 


\section{References}

1 Carel JC, Mathivon L, Gendrel C, Ducret JP \& Chaussain JL. Near normalization of final height with adapted doses of growth hormone in Turner's syndrome. Journal of Clinical Endocrinology and Metabolism 199883 1462-1466.

2 Rosenfeld RG, Attie KM, Frane J, Brasel JA, Burstein S, Cara JF, Chernause KS, Gotlin RW, Kuntze J, Lippe BM, Mahoney CP, Moore WV, Saenger P \& Johansen AJ. Growth hormone therapy of Turner's syndrome: beneficial effect on adult height. Journal of Pediatrics 1998132 319-324.

3 Haeusler G, Schmitt K, Blumel P, Plochl E, Waldhor T \& Frisch H. Growth hormone in combination with anabolic steroids in patients with Turner syndrome: effect on bone maturation and final height. Acta Paediatrica 199685 1408-1414.

4 Nilsson KO, Albertsson-Wikland K, Alm J, Aronson S, Gustafsson J, Hagenas L, Hager A, Ivarsson SA, Karlberg J, Kristrom B, Marcus C, Moell C, Ritzen M, Tuvemo T, Wattsgard C, Westgren U, Westphal O \& Aman J. Improved final height in girls with Turner's syndrome treated with growth hormone and oxandrolone. Journal of Clinical Endocrinology and Metabolism 199681 635-640.

5 Hansen I, Tsalikian E, Beaufrere B, Gerich J, Haymond M \& Rizza R. Insulin resistance in acromegaly: defects in both hepatic and extrahepatic insulin action. American Journal of Physiology 1986250 E269-E273.

6 Bratusch-Marrain PR, Smith D \& DeFronzo RA. The effect of growth hormone on glucose metabolism and insulin secretion in man. Journal of Clinical Endocrinology and Metabolism 1982 55 973-982.

7 Rizza RA, Mandarino LJ \& Gerich JE. Effects of growth hormone on insulin action in man. Mechanisms of insulin resistance, impaired suppression of glucose production, and impaired stimulation of glucose utilization. Diabetes 198231 663-669.

8 Cicognani A, Mazzanti L, Tassinari D, Pellacani A, Forabosco A, Landi L, Pifferi C \& Cacciari E. Differences in carbohydrate tolerance in Turner syndrome depending on age and karyotype. European Journal of Pediatrics 1988148 64-68.

9 Gravholt CH, Juul S, Naeraa RW \& Hansen J. Morbidity in Turner syndrome. Journal of Clinical Epidemiology 199851 147-158.

10 Gravholt CH, Naeraa RW, Nyholm B, Gerdes LU, Christiansen E, Schmitz O \& Christiansen JS. Glucose metabolism, lipid metabolism and cardiovascular risk factors in adult Turner's syndrome. The impact of sex hormone replacement. Diabetes Care 199821 1062-1070.

11 Sas T, de Muinck Keizer-Schrama S, Aanstoot HJ, Stijnen T \& Drop S. Carbohydrate metabolism during growth hormone treatment and after discontinuation of growth hormone treatment in girls with Turner syndrome treated with once or twice daily growth hormone injections. Clinical Endocrinology $2000 \mathbf{5 2}$ $741-747$

12 Sas TC, de Muinck Keizer-Schrama SM, Stijnen T, Aanstoot HJ \& Drop SL. Carbohydrate metabolism during long-term growth hormone $(\mathrm{GH})$ treatment and after discontinuation of GH treatment in girls with Turner syndrome participating in a randomized doseresponse study. Dutch Advisory Group on Growth Hormone. Journal of Clinical Endocrinology and Metabolism 200085 769-775.

13 van Teunenbroek A, de Muinck Keizer-Schrama SM, Aanstoot HJ, Stijnen T, Hoogerbrugge N \& Drop SL. Carbohydrate and lipid metabolism during various growth hormone dosing regimens in girls with Turner syndrome. Dutch Working Group on Growth Hormone. Metabolism $1999 \mathbf{4 8}$ 7-14.

14 Weise M, James D, Leitner CH, Hartmann KK, Bohles HJ \& Attanasio A. Glucose metabolism in Ullrich Turner syndrome: long-term effects of therapy with human growth hormone. German Lilly UTS Study Group. Hormone Research 199339 $36-41$.

15 Katz A, Nambi SS, Mather K, Baron AD, Follmann DA, Sullivan G \& Quon MJ. Quantitative insulin sensitivity check index: a simple, accurate method for assessing insulin sensitivity in humans. Journal of Clinical Endocrinology and Metabolism 2000852402 -2410.

16 Rolland-Cachera MF, Cole TJ, Sempé M, Tichet J, Rossignol C \& Charraud A. Body mass index variations: centile from birth to 87 years. European Journal of Clinical Nutrition 199145 3-21.

17 Tanner JM, Whitehouse RH \& Takaishi M. Standards from birth to maturity for height, weight, height velocity and weight velocity; British children 1965. Archives of Diseases in Childhood $1966 \mathbf{4 1}$ 454-471 and 613-635.

18 Greulich WW \& Pyle SL. Radiographic Atlas of Skeletal Development of the Hand and Wrist, edn 2. Stanford, CA: Stanford University Press, 1969.

19 Expert Committee on the Diagnosis and Classification of Diabetes Mellitus, Report of the Expert Committee on the Diagnosis and Classification of Diabetes Mellitus. Diabetes Care 199720 1183-1197.

20 Polychronakos C, Letarte J, Collu R \& Ducharme JR. Carbohydrate intolerance in children and adolescents with Turner syndrome. Journal of Pediatrics 198096 1009-1014.

21 Heptulla RA, Boulware SD, Caprio S, Silver D, Sherwin RS \& Tambourlane WV. Decreased insulin sensitivity and compensatory hyperinsulinemia after hormone treatment in children with short stature. Journal of Clinical Endocrinology and Metabolism $1997823234-3238$.

22 L'Allemand D, Eiholzer U, Schlumpf M, Torresani T \& Girard J. Carbohydrate metabolism is not impaired after 3 years of growth hormone therapy in children with Prader-Willi syndrome. Hormone Research 200359 239-248.

23 Fowelin J, Attvall S, Lager I \& Bengtsson BA. Effects of treatment with recombinant human growth hormone on insulin sensitivity and glucose metabolism in adults with growth hormone deficiency. Metabolism 199342 1443-1447.

24 O'Neal DN, Kalfas A, Dunning PL, Christopher MJ, Sawyer SD, Ward GM \& Alford FP. The effect of 3 months of recombinant human growth hormone (GH) therapy on insulin and glucosemediated glucose disposal and insulin secretion in GH-deficient adults: a minimal model analysis. Journal of Clinical Endocrinology and Metabolism $199479975-983$.

25 Weaver JU, Monson JP, Noonan K, John WG, Edwards A, Evans KA \& Cunningham J. The effect of low dose recombinant human growth hormone replacement on regional fat distribution, insulin sensitivity, and cardiovascular risk factors in hypopituitary adults. Journal of Clinical Endocrinology and Metabolism $1995 \mathbf{8 0}$ 153-159.

26 Bramnert M, Segerlantz M, Laurila E, Daugaard JR, Manhem P \& Groop L. Growth hormone replacement therapy induces insulin resistance by activating the glucose-fatty acid cycle. Journal of Clinical Endocrinology and Metabolism 200388 1455-1463.

27 Randle P, Garland P, Hales C \& Newsholme E. The glucose fattyacid cycle: its role in insulin sensitivity and the metabolic disturbances of diabetes mellitus. Lancet 19631 785-789.

28 Ferrannini E \& Balkau B. Insulin: in search of a syndrome. Diabetic Medicine $200219724-729$.

29 Lillioja S, Mott DM, Spraul M, Ferraro R, Foley JE \& Ravussin E. Insulin resistance and insulin secretory dysfunction as precursors of non-insulin-dependent diabetes mellitus: prospective studies of Pima Indians. New England Journal of Medicine 1993329 1988-1992.

30 De Fronzo RA \& Ferrannini E. Insulin resistance: a multifaceted syndrome responsible for NIDDM, obesity, hypertension, dyslipidemia and artherosclerotic cardiovascular disease. Diabetes Care 199114 173-194.

31 Bloomgarden ZT. Insulin resistance: current concepts. Clinical Therapeutics 199820 216-231.

Received 9 March 2004

Accepted 9 June 2004 